\title{
Development of apple chips technology
}

\author{
Hanna Kowalska $^{1}$ (D) $\cdot$ Agata Marzec $^{1} \cdot$ Jolanta Kowalska $^{2} \cdot$ Kinga Samborska $^{1} \cdot$ Małgorzata Tywonek $^{1} \cdot$ Andrzej Lenart $^{1}$
}

Received: 27 November 2017 / Accepted: 5 April 2018 / Published online: 26 May 2018

(C) The Author(s) 2018

\begin{abstract}
For develop of apple chips technology without chemical preservation osmotic dehydration in cherry or apple juice concentrates or fructooligosaccharide solutions and convection drying were used. Studies included the effect of dehydration on the mass transfer in apples and the quality of the final product. The temperature, type of osmotic solution and its concentration were changeable. The fruit were tested on mass transfer indicators, stability (water activity), texture (breaking test) and nutritional value (polyphenol content, acidity). Sensory evaluation was also performed. On this basis, the verification of all options was made and the most acceptable samples were selected. Concentration of osmotic solutions at $25^{\circ}$ Brix limited solids gain in apples. Under these conditions, the phenomenon of osmosis caused 8-10 times greater water loss than solids gain. Increasing the concentration of solutions up to $50^{\circ} \mathrm{Brix}$ had a significantly greater impact on mass exchange in apples, compared to increasing the temperature from 40 to $60^{\circ} \mathrm{C}$. Osmotic dehydration before drying did not significantly affect the water activity but increase of the temperature negatively affected on breaking force of the chips. Chips obtained by osmotic dehydration of apples in a cherry concentrate solution contained significantly more polyphenols, and were characterized by a higher acidity than the variants obtained by dehydration in concentrated apple juice. Furthermore, they were marked by red color which has been thought as part of the attractiveness of the product. The least sensory acceptable chips were prepared using osmotic pre-treatment in cherry concentrated juice solution with the addition of fructooligosaccharide.
\end{abstract}

\section{Introduction}

Apples and cherry are a seasonal fruit, however under the appropriate conditions apples can be stored and available throughout the year, in case of cherries this storage is not possible. Also harvest of cherries is also very short (about 1 month). Therefore most of these fruits are frozen or processed. The use of concentrated juices of these fruits is particularly interesting, especially the use of this concentrate for the

Electronic supplementary material The online version of this article (https://doi.org/10.1007/s00231-018-2346-y) contains supplementary material, which is available to authorized users.

Hanna Kowalska

hanna_kowalska@sggw.pl

1 Department of Food Engineering and Process Management, Faculty of Food Sciences, Warsaw University of Life Sciences (WULS), 159c Nowoursynowska St, 02-776 Warsaw, Poland

2 Department of Biotechnology, Microbiology and Food Evaluation, Division of Food Quality Evaluation, Faculty of Food Sciences, Warsaw University of Life Sciences (WULS), 159c

Nowoursynowska St, 02-776 Warsaw, Poland enrichment of food. Apples are extremely valuable raw material for processing. The fruit contain nutrient components, including dietary fiber, minerals (potassium, magnesium), vitamins (C, E, pro-vitamin A carotenes) and organic acids, pectin, lutein, folic acid [1], also polyphenols, (procyanidins, catechin, epicatechin, phloridzin, chlorogenic acid, quercetin glycosides) [2]. Intense red color, sour-sweet taste and many bioactive ingredients content (polyphenols, organic acids) of cherry fruit [3] and similarly in cherry concentrated juice make them attractive for eat and in food industry. Anthocyanins present in sour cherry fruit exhibit antioxidant, anti-inflammatory, antibacterial, and antidiabetic activities [4] but organic acids shaping its sour taste stimulate the secretion of digestive enzymes, vitamins, and minerals [5]. Polyphenols belong to natural antioxidants and are one of the most important groups playing a significant role in the human body. Most polyphenols exhibit high antioxidant activity. Together with vitamin C, E and carotenoids protect the human body from oxidative stress by preventing the formation and sweeping of free radicals and helps reduce the risk of falling into chronic diseases (cancer, heart disease) [6,7]. Polyphenols are also responsible for sensory characteristics of food. The concentration of polyphenols varies depending 
on the part of the fruit. Quercetin glycosides and flavonoids are present mainly in the skin, while phenolic acids in the apple flesh [8].

Drying is popular method for food preservation that is characterized by some advantages related to economies of storage and distribution of dried product, but it also causes significant degradation of bioactive compounds [9]. As it is a thermal process, thus providing a slowdown in enzymatic reactions and a reduction in the microorganisms. Properly selected method of drying allows obtaining a product with special form and quality characteristics. Despite convection drying (CD) causes degradation of nutrients and color change [10] the method is still worth considering due to the satisfactory efficiency at the initial period of dehydration characterized by a relatively high drying rate and large capacity [3]. Many studies related to drying were carried out with pre-treatment of raw materials and other supporting processes $[3,11]$.

Osmotic dehydration (OD) is an important operation used in food technology. The process affects the quality of the product, as the water removal is carried out without a phase transition at a moderate temperature, e.g. $50{ }^{\circ} \mathrm{C}$ [12]. This process is used to obtain minimal processed food or as a pre-drying, freezing or pasteurizing operation [13]. Used before drying can result in less energy consumption by shortening the drying time required to achieve the desired product moisture content compared to drying without pretreatment [14]. Such a treatment makes it possible to maintain the stability of the dyes present in the raw material, as well as to preserve the taste and smell. This is due to the use of an appropriate type of osmotic substance, which is an essential factor determining mass transfer in osmodehydrated material [15]. Inclusion of functional compounds, such as vitamins, minerals, probiotics to enrich food could be done by OD. In a few studies fruit or vegetable concentrated juices were added to or were used as the osmotic solutions [16]. Attempts have also been undertaken to apply juices from apples, grapes or quince fruits [16-19]. Jakubczyk and Ksionek [20] showed that the use of the dewatering in concentrates of apple and cherry allowed receiving sensory attractive products. Dehydration of fruit in apple juice significantly enhanced the taste of the raw material, while the use of cherry concentrate gave apple samples a bright red color.

The average human diet is poor in polyphenols. Also children and young people spend many hours at school and consume $35-40 \%$ of their daily calories [21]. Most of schools offer high energy foods, often due to high solid fats and added sugars. Various snacks are ubiquitous and eaten by most people. The Nielsen Company [22] reported that snack sales obtained \$374 billion annually ending March 2014 an increase of $2 \%$ year-over-year. Nowadays, the challenge for food manufacturers is to develop concepts for products with high health benefits corresponding to modern dietary trends. For this purpose raw materials of fruit and vegetables origin are useful as they are a source of valuable biological components. On the other hand, another trend is the direction of production of highly processed food ready to eat. Snack foods like fruit crisps can satisfy both of these needs. In addition, one of the ways to expand the range of offered products of this type is to propose a new, unique taste, such as cherry-flavored dried apples. Consumers are looking for products that are not only a valuable source of many macro and micronutrients but also of dietary fiber. Currently, there is growing interest in bioactive fructans, including fructooligosaccharide and inulin, which are considered to be prebiotics. Besides many healthy properties they are also important in terms of technology, including the replacement of simple sugars or fat.

Food enrichment in plant extracts or concentrated juices containing polyphenols increases the nutritional value of food $[16,23]$. Dried fruit contain more antioxidants and polyphenols than fresh one [6]. Enrichment of dried fruit during osmotic pre-treatment is a new way of enhancing the attractiveness of dried products. Such a treatment makes it possible to maintain the stability of the dyes present in the raw material, as well as to preserve the taste and smell. This is due to the use of an appropriate type of osmotic substance, which is also an essential factor determining the mass transfer [15].

The aim of the study was to development of apple chips technology using osmotic pre-treatment in cherry or apple concentrated juices and mixture of cherry juice and fructooligosaccharide solutions before convection drying. Enrichment with additional natural ingredients from fruit juices was to improve nutrients and to obtain an attractive color and taste (more fruity or slightly acidic). An additional advantage was the replacement of commonly used simple sugars (sucrose, glucose-fructose syrup) with native sugars found in fruit. Therefore a selected product characteristic was investigated and sensory evaluation was conducted to determine preference of consumers for natural apple chips.

\section{Experimental methodology}

\subsection{Materials}

Idared variety apples from the experimental field of Warsaw University of Life Sciences (Warsaw, Poland) were used for the study. The fruit without the seed chamber but with the skin were cut into slices $3 \mathrm{~mm}$ thick and $75 \pm 10 \mathrm{~mm}$ in diameter. The solutions of concentrated juices were used for the osmotic dehydration of apples:

- cherry concentrated juice (C) of extra class with extract of $67.06^{\circ}$ Brix, acidity $6.86 \%$ and turbidity 4.2 NTU - coming from the plant Bialuty Sp. zo.o. (Poland). 
- apple concentrated juice (A) of extra class with extract of $72.12^{\circ}$ Brix, acidity $2.96 \%$ and turbidity 2.1 NTU- coming from the plant Bialuty Sp. zo.o. (Poland).

The cherry and apple concentrated juices were diluted to 25 and $50^{\circ}$ Brix solutions.

The addition of fructooligosaccharide called "OF - Orafti P95" (OF) from Hortimex (Warsaw, Poland) was used for dewatering apples as a mixture with cherry concentrated juice. The cherry concentrate solutions containing OF were prepared by mixing the same mass ratio of the two solutions, respectively at concentrations of 25 and $50^{\circ}$ Brix.

\subsection{Technological methods}

\subsubsection{Preliminary osmotic treatment}

The process was carried out on a water bath JW.ELECTRW TOSM type (Warsaw, Poland) to maintain a constant temperature (40 and $60{ }^{\circ} \mathrm{C}$ ) to receive a product of high nutritional value and quality and also a moderate shaking rate of about $1 \mathrm{~Hz}$ (Kowalska et al. 2017). Experiments were carried out in mass ratio of the solution to the material at $4: 1(w / w)$ recommended by many researchers [e.g. 16, 24, 25]. After the dewatering time (30 $\mathrm{min}$ ) the samples were separated from the solution, rinsed for a few seconds under cold running tap water, dried on paper and weighed. Two repetitions were performed for each treatment.

\subsubsection{Drying}

Pre-dehydrated apples were subjected to convective drying at temperature of $60{ }^{\circ} \mathrm{C} \pm 2{ }^{\circ} \mathrm{C}$ [24]. The drying time was $4.5 \mathrm{~h}$. Apple slices were laid on the belt in a single layer in a prototype belt dryer designed and built in the Department of Food Engineering and Process Management (WULS, Warsaw, Poland) and dried in a countercurrent air flow with velocity of $1.8 \mathrm{~m} / \mathrm{s}$, determined on the basis of previous studies. The sieve load was $0.9 \mathrm{~kg} / \mathrm{m}^{2}$. The control sample was obtained by convective drying of apples without the use of osmotic pretreatment.

\subsection{Analytical methods}

\subsubsection{Identification of physical properties}

Content of dry matter (DM) [\%]) in apples was determined by gravimetric method in accordance with PN-90/A-75-75,101/ 03 in duplicate. The water activity (aw) of raw material was determined using AquaLab at $25^{\circ} \mathrm{C}$ in triplicates.

The fruit color was determined using a Minolta Chromameter300 in CIE Lab under standard illumination. The measurements were made in five replicates by randomly selecting samples.
Texture Analyzer TA - TX2 from Stable Micro Systems Ltd. of $25 \mathrm{~kg}$ was used to determine the texture of the tested material. Apple slices were subjected to a ball-head breaking test. The point breaking test was performed at a head speed of $10 \mathrm{~mm} / \mathrm{s}$ at a distance of $10 \mathrm{~mm}$ from the surface of the sample detected by the head. The value of the force was recorded using the computer program Texture. Measurement was done in 10 replications.

\subsection{Chemical analysis}

\subsubsection{Total polyphenol content}

A method based on the use of Folin-Ciocalteu reagent was applied to determine the content of polyphenols [25]. In order to obtain an extract for analysis $5 \mathrm{~g}$ of fruit was weighed with accuracy of $0.0001 \mathrm{~g}$ of particulated material. $50 \mathrm{~cm}^{3}$ of $70 \%$ methanol was added and shaken on a shaker for $1 \mathrm{~h}$. The solution was filtered with a paper filter and the supernatant extract was collected into a flask. The preparations were made in parallel with the blank specimen. Samples of $0.3 \mathrm{ml}$ of preprepared extract and $0.05 \mathrm{ml}$ of Folina-Ciocalteau reagent were taken into tubes. In the case of the test, the blank extract was replaced by the same amount of $70 \%$ methanol. Then $0.5 \mathrm{~cm}^{3}$ of $20 \%$ solution of sodium carbonate and $4.15 \mathrm{~cm}^{3}$ of distilled water were added to the samples. The contents of the flask were stirred and allowed to stand for $1 \mathrm{~h}$. The absorbance was measured at a wavelength of $\lambda=700 \mathrm{~nm}$ in the spectrophotometer He $\lambda$ ios ThermoSpectronic $\gamma$ (manufacturer: Thermo Spectronic, England) against a regent blank (without extract). Analysis was performed in four replications. The obtained absorbance value was calculated based on the equation of the calibration curve. The polyphenols was expressed in $\mathrm{mg}$ gallic acid in $100 \mathrm{~g}$ of dry matter (mg GAO/100 g d.m.).

\subsubsection{Total acidity}

Total acidity in dried apples was determined in duplicate according to PN-90/A-75-75,101/04. For the purpose of preparation $5 \pm 0.01 \mathrm{~g}$ of material was weighted in a beaker $(150 \mathrm{ml})$ and $100 \mathrm{ml}$ of distilled water was added. The solution was covered and brought to the boil. Then the samples were cooled and homogenized for $5 \mathrm{~min}$ at $850 \mathrm{rpm}$. The solution was quantitatively transferred to a $250 \mathrm{ml}$ volumetric flask and the distilled water was added to the mark and mixed well. The contents of the flask were then centrifuged using a $5000 \mathrm{rpm}$ (5 min) to obtain a clear solution for further determinations. $40 \mathrm{ml}$ of distilled water was added to $10 \mathrm{ml}$ of the solution and titrated with $0.01 \mathrm{M}$ or $0.025 \mathrm{M} \mathrm{NaOH}$ to $\mathrm{pH}=8.1$. The choice of concentration of $\mathrm{NaOH}$ solution was dependent on the type of sample and was selected to use 5 to $25 \mathrm{ml}$ of the hydroxide solution for titration. Continuous $\mathrm{pH}$ recording was done by placing the $\mathrm{pH}$ electrode in the sample. During the assay, the solution was continuously stirred with a magnetic stirrer at $580 \mathrm{rpm}$ for 
5 min. The designation was repeated twice. The result was expressed in $\mathrm{g}$ of malic acid per $100 \mathrm{~g}$ of sample.

\subsection{Sensory evaluation}

Sensory evaluation of the chips was carried out in laboratory conditions involving a 30-person evaluation team, previously introduced to the assessment methodology specified, according to the applicable standard (PN-ISO 5492:1997). Samples of 12 variants of chips (Table 1) were evaluated on a 5-point scale (PN-ISO 4121:1998) using the specific features and the corresponding boundary terms (Table 2 ).

The sample codes for sensory evaluation by scaling method and for figures are shown in Table 2. In addition, for applecherry chips, the sensory analysis was performed using the scheduling method (Table 3). Two samples, in four sets, dehydrated in solutions of the same concentration with and without addition of OF were compared (PN-EN ISO 5495:2007). It was determined which of the samples was sweeter and crispier.

\subsection{Calculation methods}

Dry matter content of osmo-dehydrated and dried apples (DM) and also mass loss (ML) were expressed in percentage [\%], water loss (WL) expressed in $\mathrm{g} \mathrm{H}_{2} \mathrm{O} / \mathrm{g}$ i. d.m. (initial dry matter content) and solids gain (SG) g/g i. d.m.] also regarding on initial dry matter content and described previously by Kowalska et al. [26] and Czajkowska et al. [19].

\subsection{Statistical methods}

Statistical analysis was performed in Statgraphics 4.1 Plus and Statistica v 12. Multivariate analysis of variance was used to determine the effect of pre-treatment on chemical and physical properties and also sensory evaluation. To evaluate the
Table 2 Specific features and boundary definitions used in sensory evaluation of dried apples (chips)

\begin{tabular}{lll}
\hline Specific features & \multicolumn{2}{l}{ Boundary definitions } \\
\cline { 2 - 3 } & 0 & 5 \\
\hline Color & Very angry & Very good \\
Smell & Atypical & Typical \\
Taste & Very angry & Very good \\
Acidity & Imperceptible or very sour & Appropriate \\
Fragility & Rubbery & Very crisp \\
Desirability & Very undesirable & Very desirable \\
\hline
\end{tabular}

dependence of the sensory evaluation on the results of experimental research and to determine the relationship between the selected qualities, a regression analysis was performed or principal component analysis PCA.

\section{Results and discussion}

\subsection{Mass transfer during osmotic dehydration}

As a result of the osmotic dehydration (OD) of apples, water removal and solids gain followed, resulting in a mass loss ML. The use of apple concentrated juice had the greatest effect on the mass loss of dehydrated fruit, whereas the mixture of cherry concentrated juice and OF caused the lowest mass loss (Fig. 1). Smaller mass loss in osmo-dehydrated apples was observed after increase of the temperature of apple and cherry concentrated juices solutions. Using the temperature of $60{ }^{\circ} \mathrm{C}$ resulted in a smaller mass loss than $40{ }^{\circ} \mathrm{C}$, which can be explained by increased solids gain at higher temperature. The largest mass loss in apples was achieved by using a $50^{\circ}$ Brix apple juice solution at $40^{\circ} \mathrm{C}$.
Table 1 Coding samples for sensory evaluation by scaling method and for figures

\begin{tabular}{lllcc}
\hline No & Code & Type of osmotic substance & Concentrate solution $\left[{ }^{\circ} \mathrm{Brix}\right]$ & Temperature $\left[{ }^{\circ} \mathrm{C}\right]$ \\
\hline 0. & Raw apple & - & - & - \\
1. & C25-40C & Cherry juice concentrate & 25 & 40 \\
2. & C25-60C & Cherry juice concentrate & 25 & 60 \\
3. & C50-40C & Cherry juice concentrate & 50 & 40 \\
4. & C50-60C & Cherry juice concentrate & 50 & 60 \\
5. & A25-40C & Apple juice concentrate & 25 & 40 \\
6. & A25-60C & Apple juice concentrate & 25 & 60 \\
7. & A50-40C & Apple juice concentrate & 50 & 40 \\
8. & A50-60C & Apple juice concentrate & 50 & 60 \\
9. & C-OF25-40C & Cherry juice concentrate+ OF & 25 & 40 \\
10. & C-OF25-60C & Cherry juice concentrate+ OF & 25 & 60 \\
11. & C-OF50-40C & Cherry juice concentrate+ OF & 50 & 40 \\
\hline
\end{tabular}


Table 3 The list of samples for sensory evaluation using the scheduling

\begin{tabular}{|c|c|c|c|c|}
\hline No of set & No of sample & Type of osmotic substance & $\begin{array}{l}\text { Concentrate } \\
\text { solution [ }{ }^{\circ} \text { Brix] }\end{array}$ & $\begin{array}{l}\text { Temperature } \\
{\left[{ }^{\circ} \mathrm{C}\right]}\end{array}$ \\
\hline \multirow[t]{2}{*}{ Set 1} & A & Cherry juice concentrate & 50 & 40 \\
\hline & $\mathrm{B}$ & Cherry juice concentrate+ $\mathrm{OF}$ & 50 & 40 \\
\hline \multirow[t]{2}{*}{ Set 2} & $\mathrm{C}$ & Cherry juice concentrate & 50 & 60 \\
\hline & $\mathrm{D}$ & Cherry juice concentrate $+\mathrm{OF}$ & 50 & 60 \\
\hline \multirow[t]{2}{*}{ Set 3} & $\mathrm{~F}$ & Cherry juice concentrate & 25 & 40 \\
\hline & $\mathrm{E}$ & Cherry juice concentrate+ $\mathrm{OF}$ & 25 & 40 \\
\hline \multirow[t]{2}{*}{ Set 4} & $\mathrm{H}$ & Cherry juice concentrate & 25 & 60 \\
\hline & $\mathrm{G}$ & Cherry juice concentrate+ $\mathrm{OF}$ & 25 & 60 \\
\hline
\end{tabular}

The type of solution, its concentration and temperature had a significant effect on the solids gain (SG) in dehydrated apples (Fig. 2a). The apple concentrated juice contributed to the largest solids gain in apples, while between the uses of cherry juice with or without C-OF no significant differences were observed (Fig. 2a). Its value was due to the chemical composition and viscosity of added juice. Lebiedzińska et al. [27] investigated apple juice and showed that the predominance of simple sugars (fructose, glucose and sucrose; 23.5-48.4\%) with low molecular weight facilitated their penetration into the dehydrated raw material. Mixture of cherry concentrated juice and OF (C-OF) contributed to increase in molecular weight of the solution and lower solids gain in apples. Piasecka et al. [28] have also shown that solutions of OF cause less growth of dry matter in dehydrated fruit compared to sucrose, due to higher molecular weight. Solutions with the same concentrations but with a higher proportion of smaller particles are characterized by higher osmotic pressure and lead to a stronger dehydration effect [15].

Solids gain increasing in dehydrated apples was observed at higher concentration of osmotic solution (Fig. 2a). In the case of apples juice solution, nearly 2-fold increase in this indicator was observed, but with a mixture of cherry juice and OF it was nearly 4-fold. Significant differences in solids

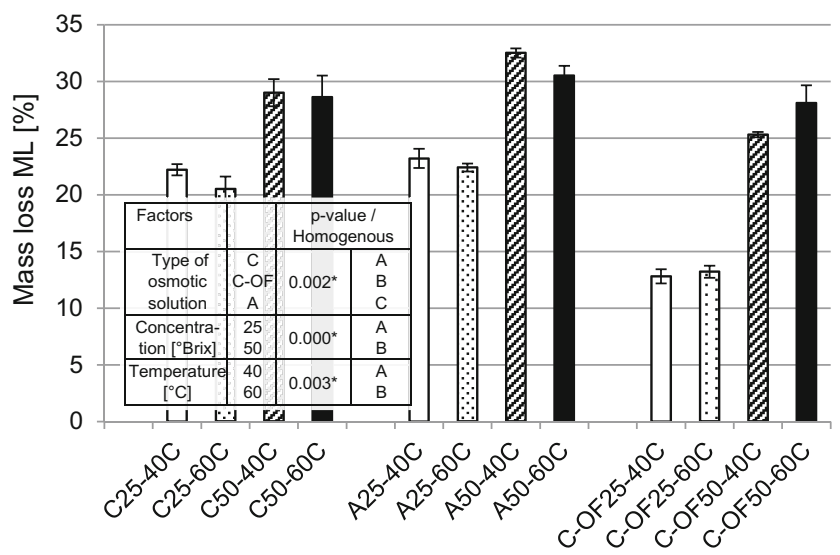

Fig. 1 The effect of type of osmotic solutions, concentration and temperature on mass loss ML of osmo-dehydrated apples. Samples codes as in Table 1 gain in apples dehydrated in this solution, both in terms of concentration and temperature may result from the combination between type of fruit juices and the temperature. Cherry juice is characterized by high acidity, because cherries contain from $0.2-0.7 \%$ in sweet cherry to $1.0-1.9 \%$ in tart cherry [29]. It can be assumed that as a result of the combination of the cherry juice with the OF solution, its stability has been reduced and broken down into lower molecular weight sugars, which are easier to penetrate into the tissue of the dehydrated material. This phenomenon has been aggravated by the increase in the proportion of cherry juice in solution as the concentration of the osmotic solution increases as well as by the higher temperature. Piasecka et al. [28] conducted a study in which they showed a decrease in the content of fructooligosaccharides in currants and cherries osmotically dehydrated due to the high temperature. This testified to the hydrolysis of sugars taken during the OD process. Klewicki and Uczciwek [30] recognized temperature $40^{\circ} \mathrm{C}$ as a level above which are significantly FOS hydrolysis.

To evaluate the influence of the osmotic solution type on the water loss to solids gain ratio WL/SG was determined. Significant influence of concentration of osmotic solution and temperature on the value of this indicator was shown (Fig. 2b). There was a tendency to decrease osmo-dehydration efficiency WL/SG with the increase of solution concentration in apples. For example, the change of cherry juice concentration from 25 to $50^{\circ}$ Brix contributed to a $55 \%$ decrease in the coefficient during the process at $40{ }^{\circ} \mathrm{C}$ and to about $37 \%$ when the process was conducted at $60{ }^{\circ} \mathrm{C}$. Konopacka et al. [24] also showed greater water loss in apples dehydrated in apple concentrate compared to fructooligosaccharide.

In most cases, decrease in the efficiency WL/SG has also been observed with the temperature increasing. Higher concentrations of osmotic solution and temperature are associated with a change in the structure of the fruit affects lower water loss and greater penetration of osmotic substances. However, especially concentrated apple juice was used in this study, and therefore, high values of SG at low values of WL/SG ratio should not be perceived negatively by consumers, particularly by those who accept fruity taste and avoid excessive intake of sugar. A similar 


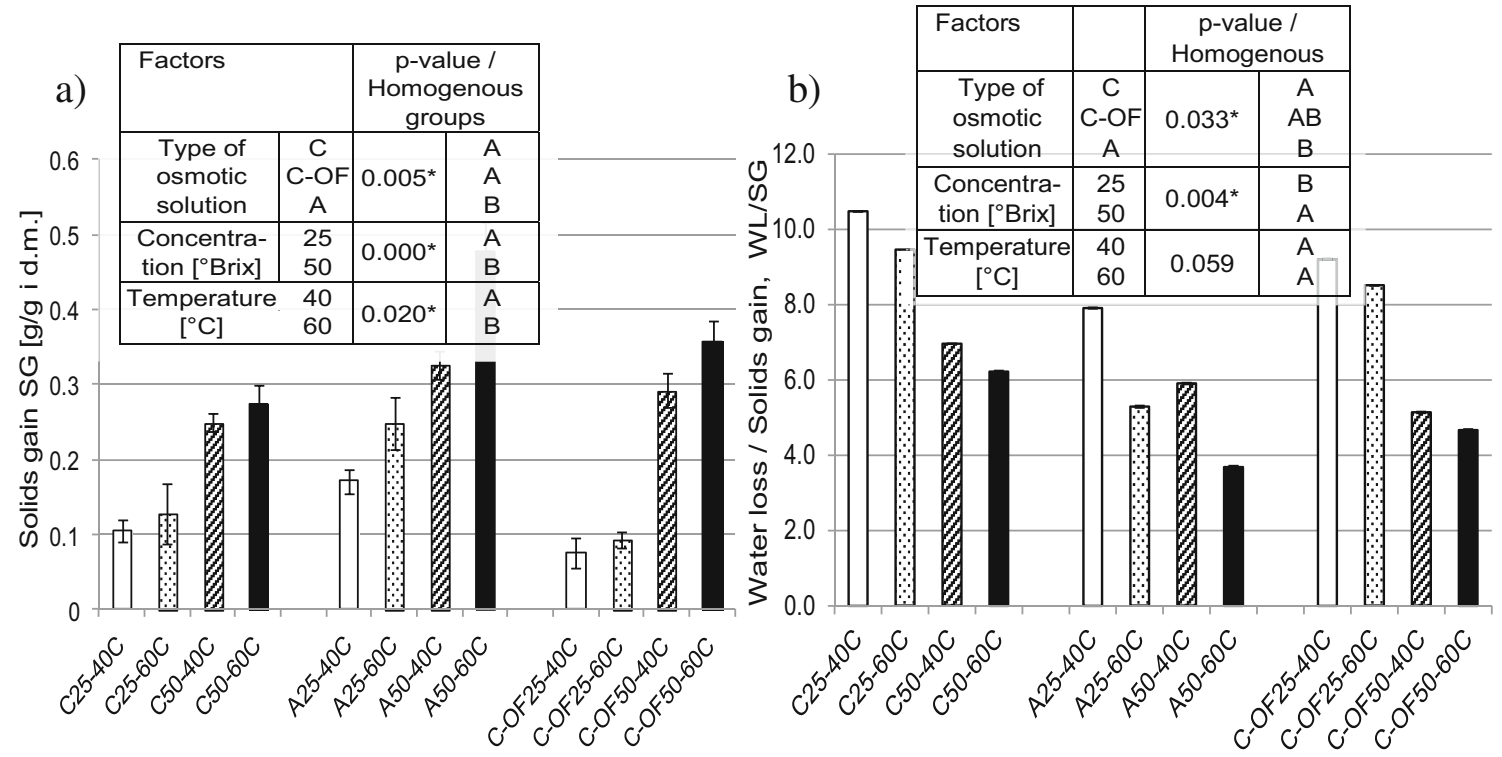

Fig. 2 The effect of type of osmotic solutions, concentration and temperature on: a) solids gain (SG), b) on dehydration efficiency (WL/SG) of osmodehydrated apples. Samples codes as in Table 1

statement can be found in the study of Nowicka et al. [3], who also obtained a lower indicator of the penetration of apple juice ingredients into dehydrated cherries.

\subsection{Properties of osmo-dehydrated and dried apple chips}

\subsubsection{Dry matter content of osmo-dehydrated and dried apples}

In all cases, a 30-min osmotic treatment resulted in a significant increase in dry matter content (DM) for all apple samples. The factors determining the intensity of mass transfer during OD were the type of osmotic solution and its concentration (Fig. 3). Apple concentrated juice had the greatest effect on the change in dry matter content DM in osmo-dehydrated apples. The cherry concentrate with OF resulted in slight (3-
13\%) lower DM compared to the use of the solution without the OF addition. All factors (type of osmotic solutions, concentration and temperature) were had a significant impact on the intensity of the mass exchange in apples. During the OD of apples in $25^{\circ}$ Brix concentrated apple juice solution at 40 and $60{ }^{\circ} \mathrm{C}$, the dry matter content in the apples was respectively about 6.4 and $7.0 \%$ lower than in the same but $50^{\circ}$ Brix-concentrate solution (Fig. 3). When using a cherry concentrated juice solution, regardless of temperature, the increase in the concentration resulted in an increase in the dry matter content of only about $5.5 \%$ and the concentrate solution of cherry juice with $\mathrm{OF}$ at $7.3 \%$ at $40{ }^{\circ} \mathrm{C}$ and $9.4 \%$ when the dewatering process was carried out at $60^{\circ} \mathrm{C}$. Konopacka et al. [24] osmodehydrated apple and cherry in apple concentrate and fructooligosaccharide solutions (at $60^{\circ} \mathrm{Brix}$ ) and showed that the use of apple concentrate resulted in increased to about $28.4 \%$ in apples and $34.8 \%$ in cherries of dry matter content to a greater
Fig. 3 The effect of type of osmotic solutions, concentration and temperature on dry matter content (DM-OD) of osmodehydrated and dried (DM-Dry) apples. Samples codes as in Table 1

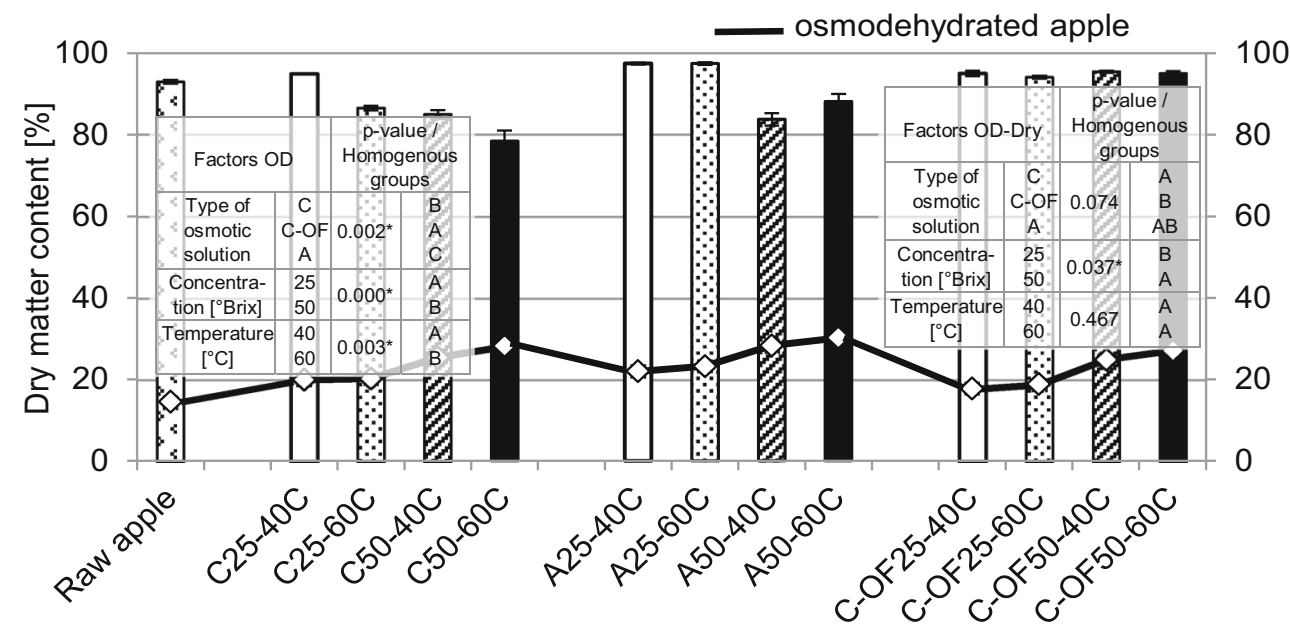


extent than the use of OF solution (respectively 19.1 and $25.7 \%$ ). This was due to the molecular weight of the dehydration solutions.

The dry matter content of dried apple slices was different from that after the initial OD. The effect of preliminary osmotic treatment on dry matter content was not shown. However the highest values for this indicator noted in dried apples obtained from fruit pre-osmo-dehydrated in $25^{\circ}$ Brix apple concentrated juice (Fig. 3). Increasing the solution concentration from 25 to $50^{\circ}$ Brix resulted in a lower dry matter value. The lowest DM was obtained in chips obtained from pre-dehydrated apples in cherry concentrated juice, especially at higher concentrations and higher temperature. The $50^{\circ}$ Brix cherry concentrated juice used to OD of apple slices at $60{ }^{\circ} \mathrm{C}$ contributed to the lowest dry matter content of about $78 \%$. Regardless of the concentration of osmotic solution and temperature in the case of chips obtained from apples dehydrated in cherry concentrated juice with $\mathrm{OF}$, the dry matter content was very similar.

It can be assumed that the dry matter content of the tested chips was more dependent on the conditions of the drying process itself and on the repeatability of the parameters such as temperature and drying time, air velocity, sieve load, which could be slightly differ for the drying process of each variant. In addition, slight variations in the dimensions of dried apple discs (both in terms of thickness and diameter) could also affect the results obtained as they significantly altered the mass transfer rate.

\subsubsection{Water activity of osmo-dehydrated and dried apples}

Apples var. Idared characterized by a water activity (Aw) of about 0.982 . Statistical analysis (Fig. 4) showed that the factors significantly affect the water activity of the dehydrated fruit was a kind of osmotic solution and its concentration. Process temperature had no significant effect on this indicator. Simultaneously the level of water activity of osmotically dehydrated apples was not sufficient to provide durability
(0.916-0.956) (Fig. 4). The lowest water activity (0.9160.930 ) was obtained by apples dehydrated in apple concentrated juice and the highest by apples dehydrated in cherry concentrated juice with OF (0.930-0.956). Increasing the concentration and temperature of the solutions resulted in a slight decrease in water activity of apples.

When the water activity of osmo-dehydrated apples was significantly affected by the type of osmotic solution and its concentration, the dried apples activity did not depend on any factors. Dried apples (chips) had water activity in the narrow range (0.283-0.350) (Fig. 4) and all were below 0.6 therefore effectively protected against microbial growth.

\subsubsection{Color parameters of osmo-dehydrated and dried apples}

The color is an important indicator of the quality of food products. It affects the consumer's senses, stimulating appetite and decides on the desirability of the product. The use of apple and cherry concentrates allowed for visually different chips. The use of fruit concentrated juices effectively stained apples and their color has also been preserved after drying. It was found that the color brightness $L^{*}$, the absolute color difference $\Delta E$ and color tone $h$ depended significantly on the type of dehydrating substances, its concentration and the temperature during OD (Table 4). No significant effect of dewatering factors on the $C$ saturation parameter was shown to be significant.

The OD of apples, independently from the conditions of its conduct, affected the decrease in the brightness of the chips compared to the dried apples without OD (Table 4). The apple concentrated juice had the slightest effect on lowering of brightness of the chips, while the cherry concentrated juice caused the greatest darkening of the color of the apple chips. The value of the $L^{*}$ parameter was even 2-fold lower compared to non-predehydrated apples. Higher concentration of osmotic solutions $\left(50^{\circ}\right.$ Brix $)$ and higher temperature $\left(60^{\circ} \mathrm{C}\right)$ resulted in darkening of the samples compared to $25^{\circ} \mathrm{Brix}$ and $40^{\circ} \mathrm{C}$ solutions.
Fig. 4 The effect of type of osmotic solutions, concentration and temperature on water activity (Aw OD) of osmo-dehydrated and dried (Aw-Dry) apples. Samples codes as in Table 1

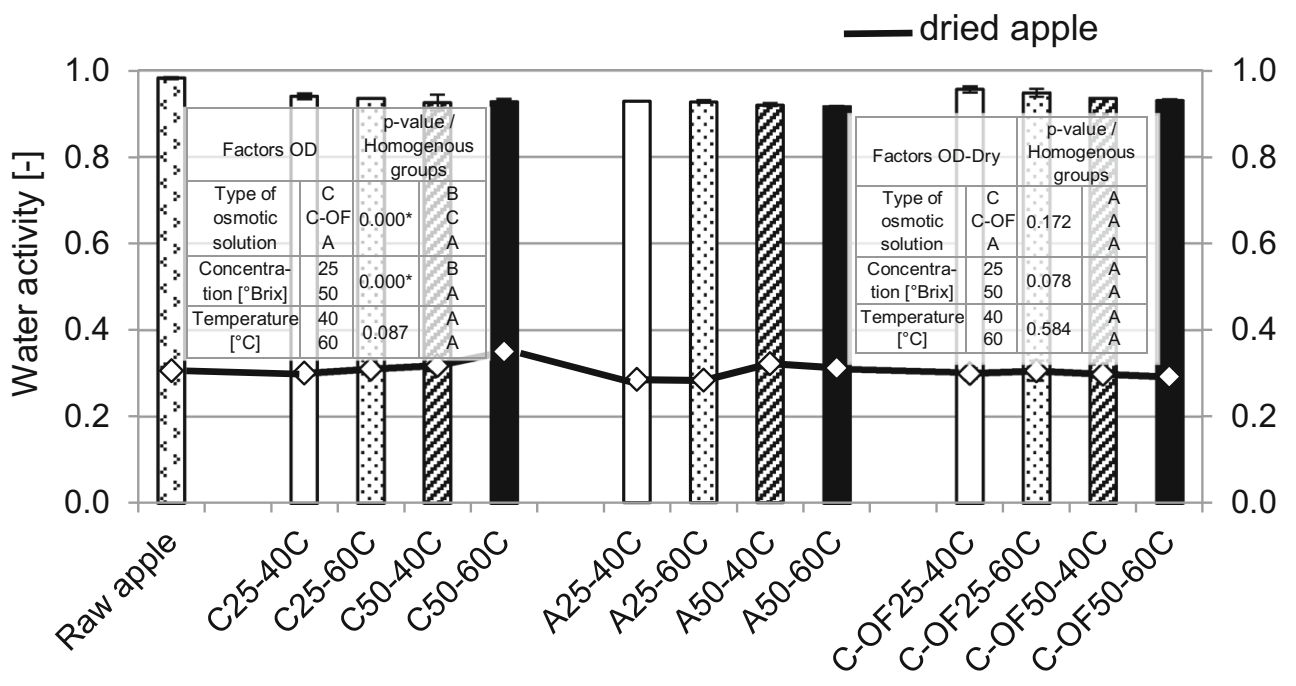




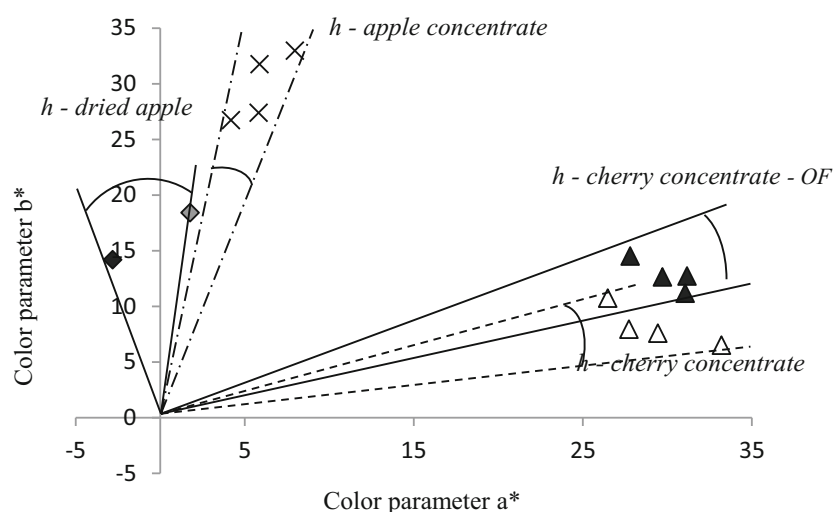

Fig. 5 Color hue angle parameter (color tone) h of apple osmodehydrated in fruit juice concentrate solutions $\left(25\right.$ and $50^{\circ}$ Brix) at 40 or $60^{\circ} \mathrm{C}$ for $30 \mathrm{~min}$ and dried by convection at temperature of $60^{\circ} \mathrm{C}$ for $4.5 \mathrm{~h}$. Other designations: $\mathrm{h}$ - dried apple - means dried samples without initial osmodehydration, $\mathrm{h}$ - apple concentrate - means osmo-pretreated samples in apple juice concentrate, $\mathrm{h}$ - cherry concentrate - OF - means osmopretreated samples in cherry juice concentrate and $\mathrm{OF}, \mathrm{h}$ - cherry concentrate - means osmo-pretreated samples in a cherry juice concentrate

Chips obtained by pre-OD in a $50^{\circ}$ Brix cherry concentrated juice solution at $60^{\circ} \mathrm{C}$ were the most different from the color of the raw material (Table 4). The absolute $\Delta E$ value of these droughts was in the range of 44-53 when the pre-dehydrated in the apple concentrated juice solution was about 2-fold lower. The most similar to the color of raw apples were chips not subjected to OD.

The color hue angle (Fig. 5) allowed the data to be divided into 4 groups, depending on the application of the osmotic solution (concentrated juice) from dehydrated cherry concentrate with the smallest hue angle (11-22), higher for predehydrated apples in cherry juice solution with OF (20-28) to the highest value (76-81) in chips pre-dehydrated in apple concentrate solution. Raw and dried apples without pre-osmotic dehydration constituted a separate group of values of $h$.

\subsubsection{Total polyphenols content of osmo-dehydrated and dried apples}

An important issue during the dehydration process of fruits is preservation of their nutritional value, especially the protection of polyphenolic compounds that directly affect the antioxidant activity and sensory characteristics of the final product [3]. The total content of polyphenols in dried apple (chips) depended only on the type of osmotic substance (Fig. 6).

However, there was a tendency to increase the content of polyphenols in chips when using higher concentration and temperature for cherry and less in the case of cherry juice with $\mathrm{OF}$. Chips obtained by drying without osmotic treatment contained 9-35\% polyphenols more than those from pre-dehydrated apples in apple concentrated juice. The use of apple concentrated juices with a lower concentration of $25^{\circ}$ Brix resulted in a 9 to $24 \%$ decrease in total polyphenols compared to apples without OD. It can be concluded that as a result of dehydration at elevated temperature and as a result of migration of polyphenols to solution additional polyphenol losses have occurred. It was also connected with mass transfer during the OD [31]. It is strongly
Table 4 Color parameters of apples osmo-dehydrated in fruit juice concentrate for $30 \mathrm{~min}$ and dried by convection for $4.5 \mathrm{~h}$. Samples codes as in Table 1 (a, b, c.. - homogenous group; the influence of the type of osmotic substance; $p<0.05$ )

\begin{tabular}{|c|c|c|c|c|c|c|}
\hline \multirow[b]{2}{*}{ Wariant } & \multicolumn{2}{|l|}{$\mathrm{L}^{*}$} & \multicolumn{2}{|l|}{$\mathrm{C}$} & \multirow[t]{2}{*}{$\Delta \mathrm{E}$} & \multirow[t]{2}{*}{$\mathrm{h}$} \\
\hline & $\mathrm{x}$ & $\mathrm{SD}$ & $\mathrm{x}$ & $\mathrm{SD}$ & & \\
\hline Raw apple & $78.8^{f}$ & 0.68 & $14.5^{\mathrm{a}}$ & 0.78 & - & $101.2^{\mathrm{d}}$ \\
\hline C25-40C & $46.6^{b}$ & 1.13 & $34.9^{\mathrm{a}}$ & 0.45 & $43.7^{\mathrm{c}}$ & $22.1^{\mathrm{a}}$ \\
\hline $\mathrm{C} 25-60 \mathrm{C}$ & $42.9^{\mathrm{a}}$ & 0.78 & $28.7^{\mathrm{a}}$ & 0.88 & $47.5^{\mathrm{c}}$ & $16.0^{\mathrm{a}}$ \\
\hline C50-40C & $41.3^{a}$ & 0.62 & $30.5^{\mathrm{a}}$ & 0.75 & $49.9^{c}$ & $14.5^{\mathrm{a}}$ \\
\hline $\mathrm{C} 50-60 \mathrm{C}$ & $40.9^{a}$ & 1.16 & $27.3^{\mathrm{a}}$ & 1.48 & $52.8^{\mathrm{c}}$ & $11.1^{\mathrm{a}}$ \\
\hline A $25-40 \mathrm{C}$ & $81.3^{\mathrm{g}}$ & 2.98 & $27.1^{\mathrm{a}}$ & 1.09 & $14.6^{\mathrm{a}}$ & $81.1^{\mathrm{c}}$ \\
\hline A25-60C & $75.5^{\mathrm{e}}$ & 1.62 & $28.0^{\mathrm{a}}$ & 1.70 & $16.1^{\mathrm{a}}$ & $77.9^{\mathbf{c}}$ \\
\hline A $50-40 \mathrm{C}$ & $76.3^{\mathrm{e}}$ & 1.98 & $32.3^{\mathrm{a}}$ & 1.38 & $19.8^{\mathrm{a}}$ & $79.5^{\mathbf{c}}$ \\
\hline A50-60C & $72.6^{\mathrm{d}}$ & 0.70 & $33.9^{\mathbf{a}}$ & 1.13 & $22.5^{\mathrm{a}}$ & $76.4^{\mathbf{c}}$ \\
\hline C-OF $25-40 \mathrm{C}$ & $57.4^{\mathrm{c}}$ & 2.46 & $33.7^{\mathbf{a}}$ & 0.60 & $37.4^{\mathrm{b}}$ & $27.6^{\mathbf{b}}$ \\
\hline C-OF $25-60 \mathrm{C}$ & $57.1^{\mathrm{c}}$ & 1.67 & $31.4^{\mathrm{a}}$ & 1.37 & $40.3^{\mathrm{b}}$ & $22.2^{\mathbf{b}}$ \\
\hline C-OF50-40C & $55.5^{\mathrm{c}}$ & 1.58 & $32.3^{\mathbf{a}}$ & 1.81 & $40.1^{\mathrm{b}}$ & $23.0^{\mathbf{b}}$ \\
\hline C-OF50-60C & $47.4^{\mathrm{b}}$ & 1.20 & $33.0^{\mathbf{a}}$ & 0.81 & $46.3^{\mathrm{b}}$ & $19.8^{\mathbf{b}}$ \\
\hline Dried apple - no OD & $84.5^{\mathrm{h}}$ & 1.88 & $18.5^{\mathrm{a}}$ & 1.40 & 8.5 & $84.5^{\mathrm{d}}$ \\
\hline Anova, $p$-values & \multicolumn{2}{|l|}{$* 0.0000$} & \multicolumn{2}{|l|}{0.4858} & $* 0.0000$ & $* 0.0000$ \\
\hline Type of osmotic substance & \multicolumn{2}{|l|}{$* 0.0130$} & \multicolumn{2}{|l|}{0.4282} & $* 0.0009$ & $* 0.0021$ \\
\hline Temperature $\left[{ }^{\circ} \mathrm{C}\right]$ & \multicolumn{2}{|l|}{$* 0.0050$} & \multicolumn{2}{|l|}{0.6032} & $* 0.0000$ & $* 0.0032$ \\
\hline Solute concentration [\%] & & & & & & \\
\hline
\end{tabular}


Fig. 6 Total polyphenols content in apple osmodehydrated in fruit juice concentrate solutions $(25$ and $50^{\circ}$ Brix) at 40 or $60{ }^{\circ} \mathrm{C}$ for $30 \mathrm{~min}$ and dried by convection at temperature of $60^{\circ} \mathrm{C}$ for $4.5 \mathrm{~h}$. Sample code as in Table 1

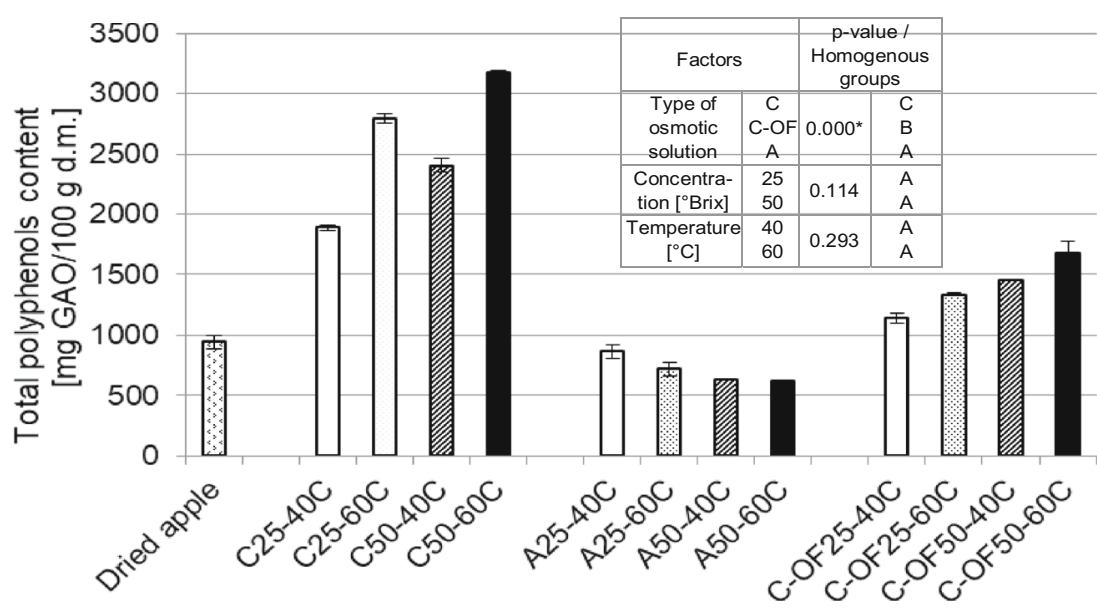

related to migration of phenolic compounds between dehydrated apples and concentrated fruit solutions and mainly with migration of solids of a low bioactive potential from the concentrate to the fruits induced by a osmotic driving force. In the study of Nowicka et al. [3] the content of polyphenols in frozen sour cherries decreased insignificantly compared with the initial material. Therefore they also noted slight degradation of polyphenols of osmo-dehydrated and dried using various methods cherries. The advisability of using prior to drying of the material by convective method before vacuum-microwave was also observed by Durance and Wang [32], who obtained lower costs of dehydration and a high nutritional value of tomatoes and strawberries. Similar results were obtained by Ścibisz and Mitek [25]. They showed that the higher polyphenols content was characterized by dried fruit with no osmotic pre-treatment.

The highest, even 2.0-3.4 fold, polyphenols content compared to dried apple without OD were chips obtained by drying previously dehydrated in cherry concentrated juice. When using it with OF, the content of polyphenols increased by $21-77 \%$ compared to the drought of non-dehydrated apples. It is not unequivocal why OD in apple concentrate adversely influences the content of polyphenolic compounds in the final products, as in apple concentrate with OF solution. There has never been carried out the OD process of apples in such medium before. Therefore, the mechanism of antioxidant activity of apples samples changes during the OD in apple concentrate solution needs more consideration. Whereas the difference in effect of cherry and apple concentrates on the content of polyphenols in dried apples results mainly from their chemical composition. Markowski and Płocharski [8] have determined the content of polyphenols in apple juice. It was 154 to $443 \mathrm{mg} \mathrm{GAO} / 1$ depending on the variety of apples and the production process. Mitic et al. [33] determined the content of polyphenols in cherry juice, which was in the range 2330-2480 $\mathrm{mg} \mathrm{GAO} / \mathrm{L}$.

The use of cherry concentrated juice is associated with great potential in developing apples (or other fruit/vegetable) chips. However the obtained results show that the attempt to apply apple concentrated juice as an osmotic solution, during combined
OD and CD method, does not contribute to the increase in the content of polyphenolic compounds and antioxidant activity of the final product. Probably, this is due to the characteristics of apple juice concentration with relatively low antioxidant activity and total polyphenol content. Therefore, to use at this stage cherry concentrated juice during the OD seems to be a much better solution to obtain effect the high increase of nutrients in dried material. In addition, OD is an important step in the production of dried fruit, because it leads to moisture content decrease to about $70 \%$. For this reason, the follow stages, such as convective drying, may be conducted in a shorter period of time, at lower temperature then traditional convective drying.

\subsubsection{Total acidity of osmo-dehydrated and dried apples}

A diversified variety of apple acid content (2.7-7.6 g/100 g) was found in the dried apples, depending on only the type of osmotic solution used during pre-dehydration (Fig. 7).

However, no significant differences were found between the content of this acid in pre-dehydrated chips in apple juice solution and cherry juice with OF. Higher acidity was associated with the penetration of high acidity cherry juice into dehydrated apples. Much lower total acidity for previously osmodehydrated apples in cherry concentrate with OF was influenced by two times lower concentration of cherry solution. During OD of apples there has been also a loss of low molecular weight acids, as a result of their leaching to solution. Also Kowalska and Jadczak [34] observed a decrease of acidity in dehydrated apples previously osmotically dehydrated.

\subsubsection{Texture of osmo-dehydrated and dried apples}

Plant tissue is characterized by heterogeneous cellular structure, susceptible to mechanical and thermal effects. Technological processes significantly affect the structure of biological material. As a result of the exchange of heat and mass, there is a tension in the tissue that results in damage to the internal structure. During drying, there is a loss of water and material shrinkage, resulting 
Fig. 7 Total acidity of apple osmo-dehydrated in fruit juice concentrates solutions $(25$ and $50^{\circ}$ Brix) at 40 or $60^{\circ} \mathrm{C}$ for $30 \mathrm{~min}$ and dried by convection at temperature of $60^{\circ} \mathrm{C}$ for $4.5 \mathrm{~h}$. Sample code as in Table 1

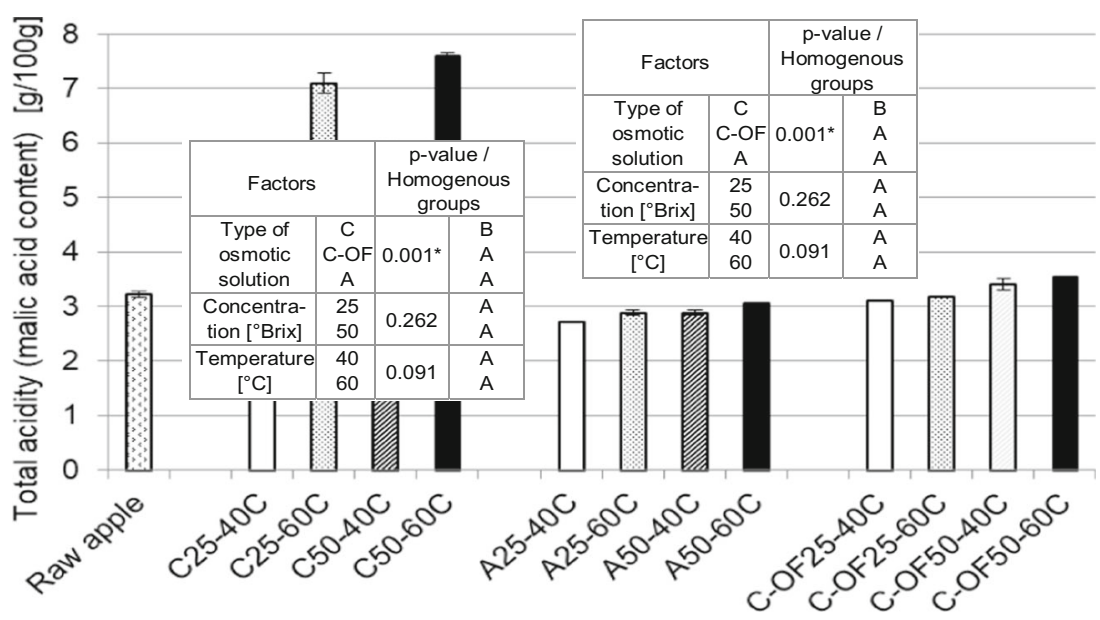

in a change in its hardness [35]. The use of OD as a pre-treatment before $\mathrm{CD}$ resulted in a strengthening of the dried apple structure compared to those without OD (Fig. 8). Only temperature of OD had a significant effect on the texture indicator of the chips.

There was a tendency to increase the breaking force of predehydrated chips in cherry and apple solutions as the concentration of solutions has changed from 25 to $50^{\circ}$ Brix at $40{ }^{\circ} \mathrm{C}$ and the opposite effect at $60^{\circ} \mathrm{C}$.

As the OD temperature increased, in all cases, the breaking force of apple chips was reduced (Fig. 8). This explains the partial destruction of the material structure during high temperature treatment. At temperature higher than $50{ }^{\circ} \mathrm{C}$, loss of cell membrane semi-permeability, nutrient losses, color and structure changes occur.

\subsubsection{Sensory evaluation of apple chips}

In order to determine the preferences of consumers regarding the obtained apple chips, a sensory evaluation consisting of two steps using the scaling and scheduling method was performed.
Scaling method The best value was obtained for apple chips color (Table 5). The highest in terms of color at very good were the chips obtained from pre-osmotic apples in cherry concentrated juice $25^{\circ}$ Brix and slightly lower in $50^{\circ}$ Brix apple juice solution. The mark of the chips taste was also very high, and dried apples with the best teste were pre-dehydrated in solution of $50^{\circ}$ Brix apple juice solution. The evaluation of apple chips in terms of smell has very similar value in the average level of 3.57. Smell of all chips produced using cherry concentrated juice with $\mathrm{OF}$ had the lowest rating. The most acidic was considered apple chips pre-dehydrated in cherry juice solution, especially those dehydrated in $50^{\circ}$ Brix solution at $60^{\circ} \mathrm{C}$. In turn, the acidity of dried apples pre-dehydrated in apple juice solution was estimated as very low.

The most varied qualitative parameter was the crispness of the chips. Pre-dehydrated at $40{ }^{\circ} \mathrm{C}$ was judged to be less crispy than dewatered at $60{ }^{\circ} \mathrm{C}$. Apple chips pre-dehydrated in $50^{\circ}$ Brix apple juice at $60{ }^{\circ} \mathrm{C}$ were considered crispy, while at least dehydrated in the same solution but at $40{ }^{\circ} \mathrm{C}$.
Fig. 8 Maximum breaking force of apple osmodehydrated in fruit juice concentrate solutions (25 and $50^{\circ}$ Brix) at 40 or $60^{\circ} \mathrm{C}$ for $30 \mathrm{~min}$ and dried by convection at temperature of $60^{\circ} \mathrm{C}$ for $4.5 \mathrm{~h}$. Sample code as in Table 1

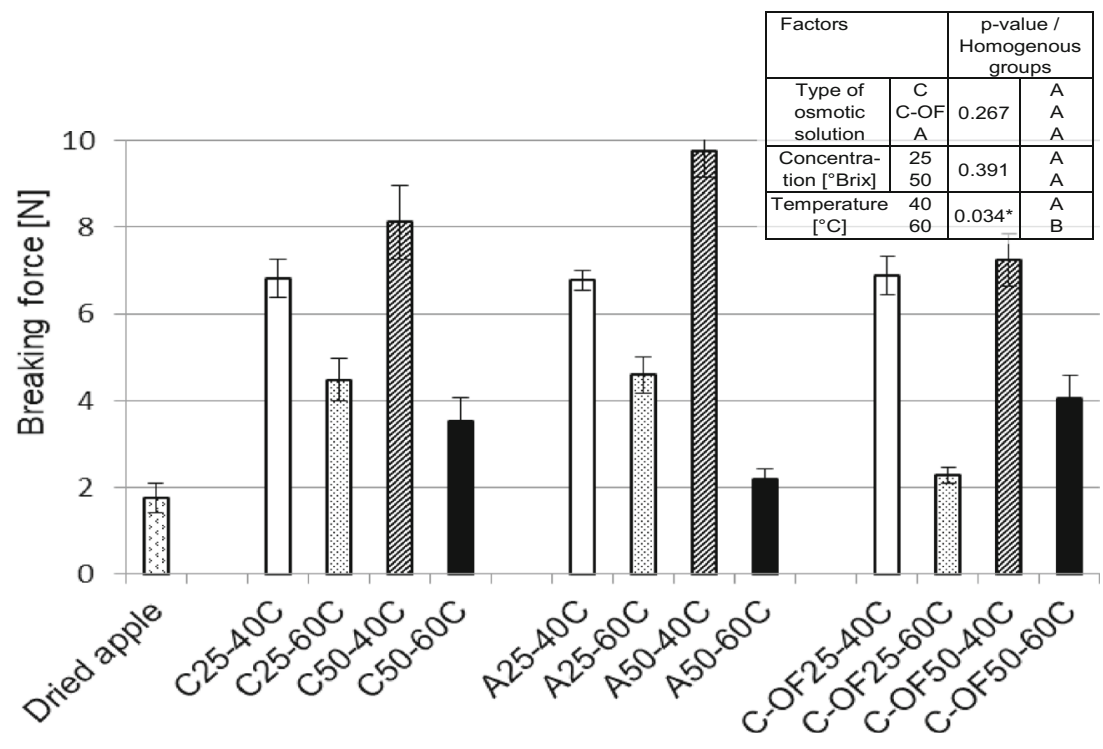


Table 5 Sensory evaluation of apple chips; scale scores 1-5, bold italic - the highest scores, bold - the lowest. Samples codes as in Table 1

\begin{tabular}{lllllllll}
\hline No. & Code & Color & Taste & Smell & Acidity & Crispy & Desirability & Average \\
\hline 1. & C25-40C & 3.85 & 4.25 & 3.45 & 3.00 & 3.00 & 3.85 & 3.57 \\
2. & C25-60C & $\mathbf{4 . 7 5}$ & 3.90 & 3.70 & 4.10 & 4.35 & 3.90 & 4.12 \\
3. & C50-40C & $\mathbf{4 . 6 5}$ & 4.05 & 3.45 & 4.05 & 2.95 & 3.40 & 3.76 \\
4. & C50-60C & 4.65 & 4.00 & 3.95 & 4.20 & 4.15 & 3.80 & 4.13 \\
5. & A25-40C & 3.90 & 3.90 & 3.65 & $\mathbf{2 . 3 5}$ & 2.55 & 3.45 & 3.30 \\
6. & A25-60C & 3.70 & 4.05 & 3.65 & 2.75 & 4.25 & 3.95 & 3.73 \\
7. & A50-40C & 4.45 & 4.50 & 3.55 & 2.50 & $\mathbf{2 . 3 5}$ & 3.90 & 3.54 \\
8. & A50-60C & 4.40 & 4.60 & 3.70 & 2.80 & 4.60 & 4.65 & 4.13 \\
9. & C-OF25-40C & $\mathbf{3 . 1 5}$ & $\mathbf{3 . 7 0}$ & $\mathbf{3 . 3 5}$ & 2.95 & 3.20 & $\mathbf{3 . 3 5}$ & $\mathbf{3 . 2 8}$ \\
10. & C-OF25-60C & 3.75 & 3.95 & 3.50 & 3.35 & 4.50 & 3.85 & 3.82 \\
11. & C-OF50-40C & 4.10 & 3.90 & 3.40 & 3.00 & 3.80 & 3.60 & 3.63 \\
12. & C-OF50-60C & 3.65 & 3.80 & 3.45 & 3.25 & 4.15 & 3.85 & 3.69 \\
& Average & $\mathbf{4 . 0 8}$ & $\mathbf{4 . 0 5}$ & $\mathbf{3 . 5 7}$ & $\mathbf{3 . 1 9}$ & $\mathbf{3 . 6 5}$ & $\mathbf{3 . 8 0}$ & $\mathbf{3 . 7 2}$ \\
& St. deviation & 0.50 & 0.27 & 0.17 & 0.62 & 0.80 & 0.34 & 0.29 \\
\hline
\end{tabular}

As a measure of the overall acceptability of the product, the determinant of desirability was assumed. Definitely the highest evaluation was attributed to chips dehydrated in apple and cherry solutions of $50^{\circ}$ Brix concentrate and temperature of $60^{\circ} \mathrm{C}$. The lowest desirability was evaluated for chips osmo-treated in concentrated cherry juice with $\mathrm{OF}$ at $25^{\circ}$ Brix at $40{ }^{\circ} \mathrm{C}$.

Scheduling method Two samples were evaluated in each sets with different the type of solution used such as cherry concentrated juice and cherry concentrated juice with OF (Table 3). Significant majority of the panelists indicated that the preosmo-dehydrated in cherry concentrated juice with $\mathrm{OF}$, e.g. B, D, F, H samples (Table 3) were sweeter and more crispy then samples dehydrated in cherry solution without OF (Fig. 9). Moreover, the OF addition did not cause significant sensory changes in the final product. OF-enriched chips have been produced due to the growing interest in fructooligosaccharides as an osmotic agent capable of contributing to the desired prebiotic properties of dehydrated fruit [28].

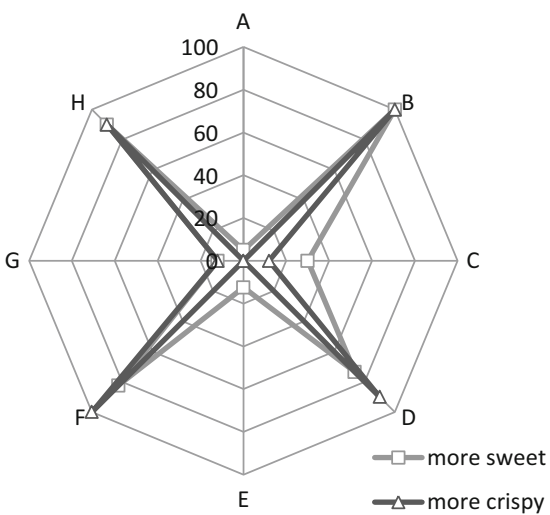

Fig. 9 The percentage of responses surveyed during the scheduling test to evaluate the osmo-dehydrated and dried samples in terms of the more sweet and more crisp in the sets composed of 2 samples. Samples codes as in Table 3
The dried apples dehydrated in solution with OF additionally had a higher dry matter content compared to chips obtained from apples dehydrated in cherry juice solution (Fig. 3).

\subsubsection{PCA analyse}

To detect similarities and differences (correlations) between analysed dried apples in terms of initial osmotic treatment and properties evaluated in terms of chemical composition, physical properties and sensory characteristics, principal component analysis with classification (PCA) was performed (Fig. 10a). Main components (PC1 and PC2) explained $76.74 \%$ variability of the properties of dried fruit.

The sensory evaluation was inversely proportional to the dry matter content of the chips (Fig. 10a). Simultaneously, greater dry matter content DM-OD was associated with decreased effectivity of OD WL/SG and water activity of osmodehydrated apples. Acidity and crispy in sensory evaluation were high correlated with value of their counterparts measured instrumentally. Very strong correlation was found between the acidity determined by the chemical assays and as sensory feature. The lower breaking strength of chips, the higher the crispy was demonstrated in sensory evaluation. Crunching and mechanical properties (breaking strength) of apple chips have the least effect on PCA (the shortest lines on the PCA diagram) and did not correlate significantly with any of the factors. This explains that all chips were comparably crispy, regardless of the conditions of their production. It was also interesting that the total polyphenols content was highly correlated with total acidity of chips and also with darkness of color (instrumentally) as a result of increasing redness, as well as with positive sensory impressions related to the color of chips (Table 4) and acidity aftertaste. The use of pre-osmotic 
a)

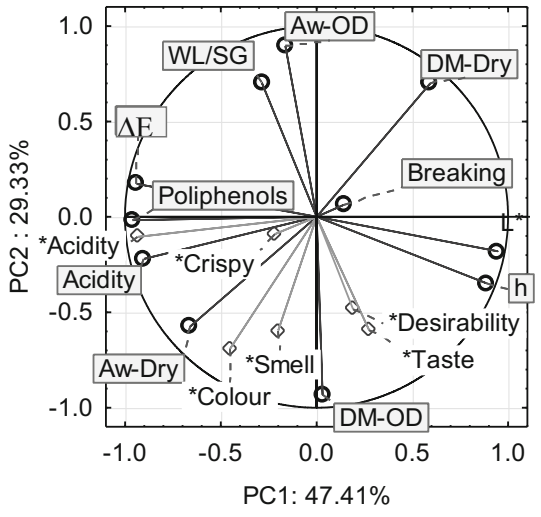

Fig. 10 PCA analysis: a) diagram PCA, b) similarities and differences. Sample code as in Tables 1 and 5. Other designations: DM - dry matter content in osmodehydrated -OD and dried apples -Dry; WL/SG - dehydration efficiency; WC - water content in chips; Aw - water activity;

dehydration with varying type of osmotic solution, its concentration and temperature allowed dividing the obtained data as in Fig. 10b. The type of osmotic solution was a major factor in the grouping.

\section{Conclusion}

Fruit concentrated juices, also with the addition of fructooligosaccharide, can be successfully used as osmotic solution for dehydration and enrichment of dried fruit. Concentration of osmotic solutions at $25^{\circ}$ Brix limited solids gain in apples. Under these conditions, the phenomenon of osmosis caused 8-10 times greater water loss than solids gain. Increasing the concentration of solutions up to $50^{\circ} \mathrm{Brix}$ had a significantly greater impact on mass exchange in apples, compared to increasing the temperature from 40 to $60{ }^{\circ} \mathrm{C}$. The decrease of $\mathrm{WL} / \mathrm{SG}$ ratio during osmotic dehydration of apple associated with increased water loss (WL) and solid gain (SG) can be considerably enhanced by cherry concentrated juice solution using before drying. Osmotic dehydration before drying did not significantly affect the water activity but increase of the temperature negatively affected on breaking force of the chips. The use of cherry concentrated juice also contributed to the high total acidity of the chips, as well as a 2-3 times higher total content of polyphenols compared to chips obtained after pre-dehydration in apple concentrated juice. Initial osmotic dehydration of apples in juice solutions improves the mechanical properties of chips. The chips obtained from apples previously treated by $50^{\circ}$ Brix solution of cherry and apple juices and temperature of $60{ }^{\circ} \mathrm{C}$ were chosen as the most attractive. Apple-cherry chips were highly evaluated for their color, smell and acidity, while apple chips were acceptable for taste, crispiness and desirability.

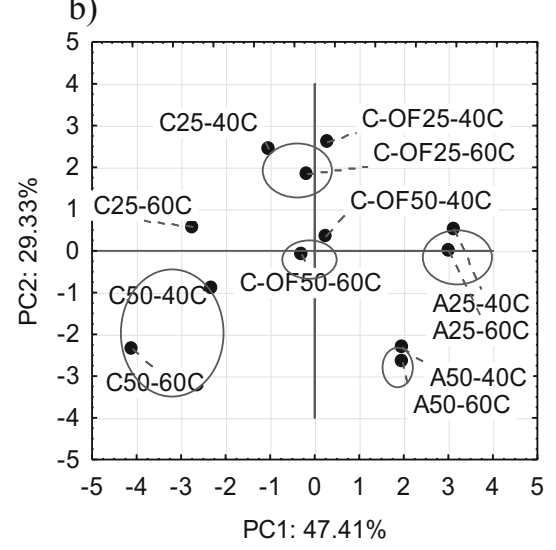

Polyphenols - total polyphenols content [mg GAE/100 g d.m.]; Acidity - total acidity [g/100 g]; Breacking - breacking strenght [N]; $\Delta \mathrm{E}$ and h - color parameters; Taste, Smell, Color, Crispy, Acidity - sensory attributes

The osmotic dehydration of apples may be conducted with using of convective drying, because it allows in relatively short time ensuring a high nutritional and sensory value of apple chips. It has also been found that apple-cherry chips are a very good alternative to dried apples with natural taste. It is distinguished by attractive red color, crispness, high content of polyphenols and acidity.

Acknowledgements This work was financially supported by a statutory activity subsidy from the Polish Ministry of Science and Higher Education for the Faculty of Food Sciences of Warsaw University of Life Sciences.

\section{Compliance with ethical standards}

Conflict of interest On behalf of all authors, the corresponding author states that there is no conflict of interest.

Human and animal studies This study does not contain any experiment involving human or animal subject

Open Access This article is distributed under the terms of the Creative Commons Attribution 4.0 International License (http:// creativecommons.org/licenses/by/4.0/), which permits unrestricted use, distribution, and reproduction in any medium, provided you give appropriate credit to the original author(s) and the source, provide a link to the Creative Commons license, and indicate if changes were made.

Publisher's note Springer Nature remains neutral with regard to jurisdictional claims in published maps and institutional affiliations.

\section{References}

1. Ferretti G, Turco I, Bacchett T (2014) Apple as a source of dietary phytonutrients: bioavailability and evidence of protective effects against human cardiovascular disease. Food Nutr Sci 5:12341246. https://doi.org/10.4236/fns.2014.513134 
2. Bondonno N, Bondonno CP, Ward NC, Hodgson JM, Croft KD (2017) The cardiovascular health benefits of apples: Whole fruit vs. isolated compounds. Trends Food Sci Technol 69:243-256. https:// doi.org/10.1016/j.tifs.2017.04.012

3. Nowicka P, Wojdyło A, Lech K, Figiel A (2015) Influence of osmodehydration pretreatment and combined drying method on the bioactive potential of sour cherry fruits. Food Bioprocess Technol 8:824-836. https://doi.org/10.1007/s11947-014-1447-y

4. Halvorsen BL, Holte K, Myhrstad MCW, Barikmo I, Hvattum E, Remberg SF et al (2002) A systematic screening of total antioxidants in dietary plants. J Nutr 132:461-471 https://www.rosavital.com/out/ pictures/media/Screening-Antioxidants.pdf Accessed 12 Mar 2018

5. Seymour M, Singer AAM, Kirakosyan A, Urcuyo-Lianes DE, Kaufman PB, Bolling SF (2008) Altered hyperlipidemia, hepatic steatosis, and hepatic peroxisome proliferator-activated receptors in rats with intake of tart cherry. J Med Food 11(2):252-259. https:// doi.org/10.1089/jmf.2007.658

6. Vinson JA, Zubik L, Bose P, Samman N, Proch J (2005) Dried fruits: excellent in vitro and in vivo antioxidants. J Am Coll Nutr 24(1):44-50. https://doi.org/10.1080/07315724.2005.10719442

7. Wojdyło A, Oszmiański J, Bielicki P (2010) Chemical composition, phenolic compounds and antioxidant activity of three varieties of apple from organic and conventional farming. Journal of Research and Applications in Agricultural Engineering 55(4):173-177 (In Polish) http://wwwpimrpoznanpl/biul/2010_4_WOBpdf Accessed 12 Mar 2018

8. Markowski J, Płocharski W (2006) Determination of polyphenols in apples and processed apple products. Journal of Fruit and Ornamental Plant Research 14(Supl.2):133-114 http://www.insad. pl/files/journal_pdf/Suppl_2_2006/Suppl_2_full_12_2006.pdf Accessed 12 Mar 2018

9. Aghbashlo M, Kianmehr MH, Hassa-Beygi SR (2010) Drying and rehydration characteristics of sour cherry (Prunus cerasus L.). J Food Process Preserv 34:351-365. https://doi.org/10.1111/j.17454549.2008.00310.x

10. Wojdyło A, Figiel A, Lech K, Nowicka P, Oszmiański J (2014) Effect of convective and vacuum-microwave drying on the bioactive compounds, color, and antioxidant capacity of sour cherries. Food Bioprocess Technol 7:829-841. https://doi.org/10.1007/ s11947-013-1130-8

11. Mayor L, Sereno AM (2004) Modeling shrinkage during convective drying of food materials: a review. J Food Eng 61:373-386. https://doi.org/10.1016/S0260-8774(03)00144-4

12. Shi J, Xue J S (2009) Application and development of osmotic dehydration technology in food processing. In: Advances in food dehydration. Ratti C. (red), CRC Press

13. Chiralt A, Talens P (2005) Physical and chemical changes induced by osmotic dehydration in plant tissues. J Food Eng 67:167-177. https://doi.org/10.1016/j.jfoodeng.2004.05.055

14. Lewicki PP, Lenart A (2007) Osmotic dehydration of fruits and vegetables. In: Handbook of industrial drying (3rd ed.). Taylor \& Francis, Boca Raton, pp 665-687

15. Phisut $\mathrm{N}$ (2012) Factors affecting mass transfer during osmotic dehydration of fruits. Int Food Res J 19(1):7-18 https://pdfs. semanticscholar.org/a74d/d9398f023a0f3757be7ce350c0a $83 \mathrm{cc} 077$ cf.pdf? ga=2.109035266.169213874.1521124411344805704.1521124411 Accessed 12 Mar 2018

16. Kowalska H, Marzec A, Kowalska J, Ciurzyńska A, Czajkowska $\mathrm{K}$, Cichowska J et al (2017) Osmotic dehydration of Honeoye strawberries in solutions enriched with natural bioactive molecules. LWT-Food Sci Technol 85:500-505. https://doi.org/10.1016/j.lwt. 2017.03.044

17. Eschriche I, Garcia-Pinchi R, Andrés A, Fito P (2000) Osmotic dehydration of kiwifruit (actinidia chinensis): fluxes and transfer kinetics. J Food Process Eng 23:191-205 http://www.academia.edu/24162101/
Osmotic_Dehydration_of_Kiwifruit_Actinidia_Chinensis_Fluxes and Mass Transfer Kinetics Accessed 12 Mar 2018

18. Figiel A (2013) Kinetics of osmotic dehydration of pumpkin slices in condensed juice from quince fruit. Advances of Agricultural Sciences Problem Issues 572:13-21 (In Polish). http://yadda.icm. edu.pl/yadda/element/bwmeta1 .element.agro-b10bdca3-36c1418e-94a9-9a582adf73dd Accessed 12 March 2018

19. Czajkowska K, Kowalska H, Cichowska J, Wojnowski M (2016) Osmotic dehydration of apples in concentrated chokeberry juice. Technological Progress in Food Processing 26/49(2):5-11 (In Polish). http://wsm.warszawa.pl/wydawnictwo/postepy-technikiprzetworstwa-spozywczego. Accessed 12 Mar 2018

20. Jakubczyk E, Ksionek U (2006) The mechanical properties of dried apple with an average water content. Agricultural Engineering 7(82):215-222 (In Polish). https://ir.ptir.org/artykuly/pl/82/ IR(82)_252_pl.pdf Accessed 12 Mar 2018

21. Mann G, Hosig K, Zhang A, Shen S, Serrano E (2017) Smart snacks in school legislation does not change self-reported snack food and beverage intake of middle school students in rural Appalachian region. J Nutr Educ Behav 49(7):599-604. https:// doi.org/10.1016/j.jneb.2017.05.338

22. Website (2014) Nielsen Global Snacking Report September 2014.pdf http://www.nielsen.com/content/dam/nielsenglobal/kr/ docs/global-report/2014/Nielsen\%20Global\%20Snacking\% 20Report\%20September\%202014.pdf. Accessed 3 Oct 2017

23. Gramza-Michalowska A, Regula J (2007) Use of tea extracts (Camelia sinensis) as polyphenols sources in human diet. Asia Pac J Clin Nutr 16:43-46 https://pdfs.semanticscholar.org/b83a/ 0a3221f0c73d21e1140ac4351f9b94cb1fab.pdf Accessed 12 March 2018

24. Konopacka D, Jesionkowska K, Klewicki R, Bonazzi C (2009) The effect of different osmotic agents on the sensory perception of osmo-treated dried fruit. J Hortic Sci Biotechnol, ISAFRUIT Special Issue 84:80. https://doi.org/10.1080/14620316.2009. 11512600

25. Ścibisz I, Mitek M (2006) Antioxidant activity and content of phenolic compounds in blueberries (Vaccinium corymbosum L.). FoodScience-Technology-Quality 4(49):68-76 (In Polish). http:// journal.pttz.org/wp-content/uploads/2015/02/21 Scibisz.pdf Accessed 12 Mar 2018

26. Kowalska H, Lenart A, Leszczyk D (2008) The effect of blanching and freezing on osmotic dehydration of pumpkin. J Food Eng 86: 30-38. https://doi.org/10.1016/j.jfoodeng.2007.09.006

27. Lebiedzińska A, Czaja J, Brodowska K, Woźniak A, Szefer P (2011) Evaluation of simple sugars and sucrose in fruit juices using HPLC. Bromatology and Toxicological Chemistry 3: 326-330 (In Polish)

28. Piasecka E, Uczciwek M, Klewicki R (2009) Osmotic dehydration of fruits in solutions containing fructooligosaccharides. FoodScience-Technology-Quality 2(63):138-153 (In Polish), https:// wwwresearchgatenet/publication/286866821_Osmotic dehydration of fruits in solutions containing fructooligosaccharides Accessed $1 \overline{2}$ Mar 2018

29. Stéger-Máté M (2012) Sweet \& Tart Cherries. In: Nirmal KS, Jiwan SS, Jozsef B, James S, Pilar Cano M (eds) Handbook of Fruits and Fruit Processing, Second Edition. Wiley \& Sons, Inc 26: pp. 433-446

30. Klewicki R, Uczciwek M (2008) Effect on osmotic dehydration in fructose, sucrose and fructooligosaccharide solutions on the content of saccharides in plums and apples and their energy value. Agric Food Sci 17:367-375. https://doi.org/10.2137/145960608787235559

31. Tylewicz U, Panarese V, Laghi L, Rocculi P, Nowacka M, Placucci G, Dalla RM (2011) NMR and DSC water study during osmotic dehydration of Actinidia deliciosa and A. Chinensis kiwifruit. Food Biophys 6:327-333. https://doi.org/10.1007/s11483-011-9210-7

32. Durance TD, Wang JH (2002) Energy consumption, density, and rehydration rate of vacuum-microwave and hot air convection- 
dehydrated tomatoes. J Food Sci 67(6):2212-2216. https://oi.org/ 10.1111/j.1365-2621.2002.tb09529.x

33. Mitić M, Obradović M, Kostić D, Nasković D, Micić R (2011)

Phenolics content and antioxidant capacity of commercial red fruit juices. Hemijska Industrija 65(5):611-619 UDC 663.81(4987.11): 547.56:615

34. Kowalska H, Jadczak S (2007) Osmotic dehydration of apples in sucrose and ascorbic acid solutions. Food-Science-Technology-
Quality 3(52):119-126 (In Polish). http://journal.pttz.org/wpcontent/uploads/2015/02/12 Kowalska.pdf

35. Lewicki PP, Porzecka-Pawlak R (2005) Effect of osmotic dewatering on apple tissue structure. J Food Eng 65:519-525. https://doi.org/10.1016/j.jfoodeng.2004.02.032 